\title{
Problematika Kebijakan Penegakan Hukuman Pidana Mati Untuk Koruptor Pada Masa Pandemi Corona Virus Disease 2019 (Covid-19)
}

\author{
Wildan Tantowi ${ }^{1}$, N.G.A.N Ajeng Saraswati ${ }^{2}$, Viola Sekarayu Gayatri ${ }^{3}$ \\ 1. Faculty of Law, Universitas Sebelas Maret.E-mail: wildantantowi@gmail.com \\ 2. Faculty of Law, Universitas Sebelas Maret.E-mail: ayuajengsaraswati@gmail.com \\ 3. Faculty of Law, Universitas Sebelas Maret. E-mail: violasekarayug@yahoo.com
}

\begin{abstract}
This research examines the problems arising from the criminal law policy of imposing the death penalty for corruptors during the Covid-19 pandemic. Corruption is categorized as extraordinary crime. The corruption eradication should also be carried out in an extraordinary way. Law Number 31 of 1999 which has been amended by Law Number 20 of 2001 concerning the Eradication of Corruption Crimes is one of the weapons to fight corruption in Indonesia, especially during the Covid-19 pandemic as a national nonnatural disaster which has been a serious concern of the government. In the event of corruption cases occur during the Covid-19 pandemic, such criminal cases should be tackled in an extraordinary and special way because the impact of Covid-19 pandemic has affected all sectors of life, one of which is the economy. Considering the Covid-19 pandemic, it is appropriate if Indonesia is currently categorized under certain conditions. It means that this condition implies that if a criminal act of corruption occurs during the Covid19 pandemic, law enforcers can prosecute or impose a death penalty for corruption perpetrators as stipulated in Article 2 paragraph (1) and (2) of the Corruption Eradication Law. This research used the normative legal method which is carried out through literature study with the aim of writing the article to find out what weaknesses can lead to juridical problems with the enforcement of the death penalty against corruptors in Indonesia and to analyze the urgency of criminal law policy $n$ the imposition of the death penalty for corruptors during the Covid-19 pandemic.
\end{abstract}

Keywords: Corruption Criminal Act, Death Penalty Imposition, Covid-19 Pandemic

\section{Pendahuluan}

Penegakan hukum pidana merupakan sebuah keniscayaan yang harus diwujudkan dalam kerangka sebuah kebijakan hukum pidana yang merupakan bagian dari politik hukum nasional. Upaya penanggulangan kejahatan dilakukan untuk mencapai tujuan akhir kebijakan hukum pidana, yaitu menciptakan ketertiban dan kesejahteraan dalam rangka memberikan perlindungan terhadap masyarakat (Ariyanti, 2019). Kebijakan hukum pidana merupakan sebuah mekanisme yang menjamin aturan aturan yang ada dapat berlaku secara adil dan tegas dengan di dukung oleh Aparat Penegak Hukum yang berintegritas merupakan sebuah konsep nyata dalam upaya penegakan hukum.

Tindak pidana korupsi telah menjadi sebuah kejahatan yang terstruktur sistematis dan meluas dalam ruang lingkup lini kehidupan. Hal ini menjadikan korupsi sebagai kejahatan luar biasa (extraordinary crime). Tindak pidana korupsi tidak hanya merugikan negara secara ekonomi dan keuangan tetapi juga pelanggaran terhadap hak-hak sosial masyarakat yang terdampak dari adanya praktik korupsi. Korupsi sebagai extraordinary 
crime dalam pemberantasannya juga harus dilakukan dengan langkah-langkah yang luar biasa. Salah satu efek penjeraan yang ingin diberikan kepada para koruptor di Indonesia adalah dengan adanya sanksi pidana mati yang telah diatur dalam Undang-Undang Nomor 31 Tahun 1999 sebagaimana telah diperbarui dalam Undang-Undang Nomor 20 Tahun 2001 tentang Pemberantasan Tindak Pidana Korupsi (UU Tipikor) (Astuti, 2016).

Isu yang sedang hangat akhir-akhir ini adalah terjeratnya Mentri Sosial Republik Indonesia, Juliari Batubara dalam kasus suap bantuan sosial Covid-19 yang sampai saat masih ditangani oleh Komisi Pemberantasan Korupsi (KPK) dan diduga Mentri Sosial, Juliari Batubara menerima uang sebesar Rp 8,2 Miliar. Pengadaan Bansos Covid-19 berupa paket sembako di Kementerian Sosial Republik Indonesia dengan nilai Rp 5,9 triliun dengan 272 kontrak untuk dilaksanakan dalam dua periode. KPK menduga ada kesepakatan sejumlah fee dari penunjukan rekanan pengadaan Bansos Covid-19 dan fee tersebut juga diduga diterima oleh Mentri Sosial, Juliari Batubara (Detik News, 2020). Keadaan Indonesia yang masih bergulat dengan pandemi Covid-19 menjadikan Indonesia masuk dalam kondisi keadaaan tertentu. Keadaan tertentu yang diatur dalam UndangUndang Nomor 31 Tahun 1999 yang telah diperbarui dengan Undang-Undang Nomor 20 Tahun 2001 tentang Pemberantasan Tindak Pidana Korupsi (UU Tipikor) telah mengatur apabila terjadi tindak pidana korupsi dalam keadaan tertentu, Aparat Penegak Hukum dapat menuntut ataupun menjatuhkan pidana mati terhadap pelaku.

Namun, di sisi lain Institute For Criminal Justice Reform (ICJR) menentang keras wacana penerapan pidana mati kasus korupsi sebagai solusi dari pemberantasan korupsi khususnya dalam kondisi pandemi saat ini. Hal yang menjadi rekomendasi dari ICJR dalam penanggulangan korupsi dengan fokus memperbaiki sistem pengawasan pada titik-titik kerja pemerintahan yang dalam kasus ini adalah penyaluran bantuan sosial pandemi Covid-19. Selama ini penjatuhan pidana mati di Indonesia hanya dijadikan sebagai narasi populis yang membuat seolah-olah pemerintah bekerja secara tegas dalam menanggulangi korupsi tetapi pada faktanya penjatuhan pidana mati tidak akan menyelesaikan permasalahan kejahatan yang dihadapi (Institute For Criminal Justice Reform, 2020).

Selain itu, ICJR memperkuat dengan Indeks Prestasi Korupsi (IPK) tahun 2019 menyatakan bahwa negara yang efektif melakukan pemberantasan korupsi tidak memberlakukan pidana mati sebagai pemidanaan seperti Denmark, Selandia Baru dan Finlandia sedangkan Indonesia yang nyatanya terdapat ancaman pidana mati untuk pelaku korupsi menduduki peringkat 85. Sehingga menurut ICJR pembaruan sistem pengawasan yang harus dirombak daripada bersikap reaktif dengan menjatuhkan hukuman mati (Institute For Criminal Justice Reform, 2020)

Berdasarkan dari kasus korupsi yang menyeret Mentri Sosial, Juliari Batubara di saat Indonesia sedang mengalami pandemi Covid-19 dan berdasarkan aturan dalam UU Tipikor bahwa koruptor dapat dijatuhi pidana mati apabila melakukan tindak pidana korupsi dalam keadaan tertentu. Maka pembahasan dalam artikel ini mengerucutkan rumusan masalah sebagai berikut : Bagaimana problematika yuridis penjatuhan pidana mati kepada koruptor di Indonesia? Dan Bagaimana urgensi kebijakan hukum pidana di Indonesia dalam penjatuhan pidana mati bagi koruptor berdasarkan Undang-Undang Pemberantasan Tindak Pidana Korupsi pada masa pandemi Covid-19? 


\section{Metode Penelitian}

Metode penelitian yang digunakan dalam penulisan artikel ini menggunakan metode penelitian hukum normatif yang dilakukan melalui studi kepustakaan dengan menggali menggunakan data sekunder berupa bahan hukum primer dan bahan hukum sekunder. Bahan hukum primer berupa peraturan perundang-undangan terkait dan bahan hukum sekunder berupa buku, jurnal atau publikasi hukum (Marzuki, 2017). Penelitian dalam artikel ini difokuskan untuk mengkaji problematika yuridis yang terdapat dalam penjatuhan pidana mati terhadap pelaku tindak pidana korupsi di Indonesia serta penerapan kebijakan hukum pidana di Indonesia terhadap penjatuhan pidana mati dalam UU Tipikor pada masa pandemi Covid-19.

3. Hasil Penelitian

\section{Problematika Yuridis Pejatuhan Pidana Mati Terhadap Koruptor Di Indonesia}

Korupsi merupakan kejahatan yang luar biasa (extraordinary crime) yang dapat menghancurkan moral bangsa dan membuat kerugian negara yang berimbas pada terhambatnya pembangunan serat yang paling vital adalah menutup koridor keadilan, kemakmuran dan kesejahteraan bangsa Indonesia. Sanksi pidana mati merupakan salah satu opsi pemidanaan dalam sistem hukum di Indonesia. Sanksi pidana mati dapat dijatuhkan kepada pelaku tindak pidana korupsi di Indonesia yang dilatarbelakangi secara filosofis oleh nilai moral Pancasila. Sanksi pidana mati seperti yang tercantum dalam Undang-Undang Nomor 31 Tahun 1999 sebagaimana telah diperbarui dalam Undang-Undang Nomor 20 Tahun 2001 tentang Pemberantasan Tindak Pidana Korupsi (UU Tipikor) harus dapat didialogkan dengan hukum kodrat Pancasila dalam menguji keadilan hukumnya bukan pada level atau tataran keadilan tindakannya (Amirullah, 2013).

Jerat pidana yang dapat dikenakan kepada koruptor adalah pidana mati sebagaimana diatur dalam Pasal 2 Ayat (1) dan (2) UU Tipikor, sebagai berikut :

(1) Setiap orang yang secara melawan hukum melakukan perbuatan memperkaya diri sendiri atau orang lain atau suatu korporasi yang dapat merugikan keuangan negara atau perekonomian negara, dipidana penjara dengan penjara seumur hidup atau pidana penjara paling singkat 4 (empat) tahun dan paling lama 20 (dua puluh) tahun dan denda paling sedikit Rp. 200.000.000,00 (dua ratus juta rupiah) dan paling banyak $R p$. 1.000.000.000,00 (satu milyar rupiah).

(2) Dalam hal tindak pidana korupsi sebagaimana dimaksud dalam ayat (1) dilakukan dalam keadaan tertentu, pidana mati dapat dijatuhkan.

Namun, pada realitanya sampai saat belum pernah ada penjatuhan sanksi pidana mati di Indonesia meskipun perbuatan koruptor tersebut telah terdapat kesalahan yang harus dipertanggungjawabkan. Hal ini pula menjadikan Indonesia dijadikan sebagai wahana yang indah bagi para koruptor, karena ancaman pidana mati yang tercantum dalam UU Tipikor belum pernah di eksekusi dan pastinya pengaturan hukuman mati bagi koruptor menjadi terabaikan. Hal ini disebabkan dari perumusan pidana penjatuhan pidana mati bagi koruptor hanya terdapat di Pasal 2 ayat (2) 
Undang-Undang Tipikor dan syarat penjatuhannya pun sangat sulit untuk diterapkan (Batubara, 2014).

Fakta dari ancaman pidana mati yang tercantum dalam UU Tipikor sampai saat ini belum pernah diterapkan terhadap koruptor disebabkan karena masih terdapat problematika yuridis dari formulasi penjatuhan pidana mati yang masih mempunyai beberapa kelemahan. Pertama, kelemahan dalam sisi substansi hukum bahwa pidana mati hanya dapat diancamkan atau diterapkan terhadap tindak pidana memperkaya diri sendiri/orang lain/koorporasi yang dilakukan saat keadaan tertentu. Hal ini menjadi kelemahan yang cukup vital ketika ditambah dalam UU Tipikor tidak dirumuskan mengenai batasan pengulangan (recidive) tindak pidana korupsi (Arief, 2013).

Kelemahan substansi hukum yang lain ketika ketentuan Pasal 2 ayat (2) UU Tipikor merumusakan kata "dapat" dalam pasal tersebut, sehingga penjatuhan pidana mati bagi koruptor yang melakukan korupsi pada keadaan tertentu bersifat fakultatif yang artinya bisa saja tidak dijatuhi hukuman mati dan kata "dapat" dalam pasal tersebut juga bermakna subjektif yang artinya dapat disalahartikan dalam rangka meringankan koruptor (Katimin, 2020)

Kedua, kelemahan dalam sisi struktur hukum. Hal ini mengacu masih terjadinya silang kepentingan antar Aparat Penegak Hukum, kewenangan penyidikan dapat dilakukan oleh Komisi Pemberantasan Korupsi (KPK) dan juga Kepolisian. Kemudian wewenang menuntut yang biasanya dilakukan oleh Kejaksaan dapat di overlaping oleh KPK. Tumpang tindih wewenang dan yurisdiksi antar lembaga pemerintahan ini memunculkan masalah struktural yang berpotensi memunculkan adanya gesekan antar lembaga dan berimbas pada vonis yang dijatuhkan terhadap koruptor tidak maksimal, sehingga tidak ada efek jera bagi koruptor (Astuti, 2016).

Ketiga, kelemahan dalam sisi kultur hukum. Lagi-lagi masih terdapat pro dan kontra dari kebijakan pidana mati tersebut. Terdapat anggapan bahwa penjatuhan pidana mati sama saja dengan pelanggaran HAM. Pada prinsipnya hak asasi manusia adalah hak asasi/hak kodrat/hak mutlak milik umat manusia, orang per orang yang dimiliki umat manusia sejak lahir sampai dengan meninggal dunia; sedangkan dalam pelaksanaannya didampingi oleh kewajiban dan tanggungjawab. Mengingat hak asasi manusia adalah hak dasar yang dibawa manusia sejak lahir sebagai anugrah Tuhan Yang Maha Esa, maka hak asasi manusia tersebut tidaklah bersumberdari Negara, tetapi semata-mata bersumber dari Tuhan sebagai pencipta alam semesta raya beserta isinya, sehingga hak asasi manusia itu tidak dapat dikurangi (Non Derogable Rights). Oleh karena itu, yang diperlukan dari negara hukum itu adalah suatu jaminan perlindungan terhadap hak asasi manusia tersebut (Manan, 2001).

Problematika ini menjadi muara apakah penjatuhan pidana mati bagi koruptor di Indonesia layak untuk diterapkan. Faktanya aturan hukum seolah dibuat tidak berdaya untuk menyentuh pejabat tinggi yang melakukan korupsi dengan adanya kata "dapat" dalam pasal UU Tipikor yang merekonstruksi dijatuhkannya pidana mati bagi koruptor. Kata "dapat" bersifat subjektif ditambah dengan perangkat hukum yang lemah dalam mengatasi korupsi. Narasi penjatuhan pidana mati bagi koruptor 
sering digaungan bagi mereka yang pro dengan hukuman mati tetapi ada pihak yang kontra dengan hukuman mati karena melanggar Hak Asasi Manusia. Sehingga akan selalu ada polemik mengenai kebijakan hukuman mati bagi koruptor (Surahmad, 2016).

Menurut Institute For Criminal Justice Reform (ICJR) paradigma pemidanaan juga telah bergeser dari teori retibutif (pembalasan) menuju arah teori restoratif. Hal ini didasari oleh fakta dalam data indeks presatsi korupsi, negara yang menempati peringkat tertinggi dalam menanganani tindak pidana korupsi tidak menerapkan hukuman mati. Selain itu, mitos dari pemberian efek jera dalam penjatuhan pidana mati juga belum dapat dibuktikan dalam penelitian ilmiah. Sekali tiga uang dengan Indonesia, narasi penjatuhan pidana mati bagi koruptor hanya menjadi sebuah fenomen penal populism yang termanifestasi dalam pengambilan kebijakan hukum yang irrasional dengan mengeksploitasi kemarahan publik terhadap korupsi guna membangun sentimen punitif yang semata-mata untuk meraih reputasi dan simpati publik (Iftitahsari, 2020).

Selain terdapat pihak yang kontra terhadap hukuman mati, terdapat juga pihak yang pro dengan hukuman mati. Hal ini didasari dengan alasan pelaku tindak pidana korupsi dapat dijatuhi hukuman yang seberat-beratnya atas perbuatan yang diperbuatnya. Setiap perbuatan yang mengandung unsur kesalahan atau tindak pidana, makan unsur tersebut yang dapat menyebabkan seseorang itu dihukum sebagaimana dikeal dengan asas tiada pidana tanpa kesalahan (Geen straf zonder schuld atau no punishment without guilt) yang merupakan asas pokok dalam pertanggungjawaban pidana (Yanto, 2017).

Pemberian sanksi pidana mati terhadap pelaku tindak pidana korupsi dinilai masih pantas untuk diterapkan. Melihat dampak yang ditimbulkan dari korupsi yang mengakibatkan kehancuran yang luar biasa bagi kehidupan bangsa. Tidak hanya hancur dari sisi ekonomi saja tetapi sisi moralitas bangsa juga turut terdegradasi dari tindak pidana korupsi yang seolah menjadi 'budaya' yang mengakar dari bangsa ini. Efek yang ditimbulkan pun akan semakin berkelanjutan dan posisi bangsa Indonesia pun makin rendah di dunia internasional apabila tidak mampu mengendalikan korupsi (Anshari \& Fajrin, 2020)

Berdasarkan United Nations Corruption Againts Convention (UNCAC) tahun 2003 yang telah diratifikasi dengan Undang-Undang Nomor 7 Tahun 2006 tentang Pengesahan United Nation Convention Againts Corruption tanggal 18 April 2006, menyatakan korupsi sebagai persoalan yang serius dan mengancam stabilitas dan keamanan masyarakat, melecehkan lembaga-lembaga dan nilai-nilai demokrasi, nilai etika dan keadilan, serta membahayakan pembangunan berkelanjutan dan aturan hukum. Hal ini sesuai dengan ketentuan Pasal 6 ayat (2) International Covenant on Civil and Political Rights (ICCPR) yang masih membolehkan penerapan pidana mati pada jenis kejahatan yang bersifat serius. Mendasarkan pada ketentuan tersebut, pidana mati tidak bertentangan dengan ketentuan Internasional (Anjari, 2020) 
UIRLawReview. 5(1): 49-58

\section{Urgensi Kebijakan Hukum Pidana Di Indonesia Dalam Penjatuhan Pidana Mati Bagi Koruptor Berdasarkan Undang-Undang Pemberantasan Tindak Pidana Korupi Pada Masa Pandemi Covid-19}

Menurut Busyro Muqodas terdapat tiga kriteria utama yang dapat dijadikan dasar koruptor dapat dijatuhi hukum mati. Pertama, kerugian yang dialami negara ditaksir lebih dari 100 miliar dan secara masif menimbulkan kerugian bagi rakyat. Kedua, pelaku korupsi adalah pejabat negara dan ketiga, pelaku korupsi melakukan korupsi berulang-ulang (Toule, 2013).

Tindak pidana korupsi merupakan kejahatan luar biasa (extraordinary crime) yang menjadi salah satu bagian dari hukum pidana yang bersifat khusus, Undang-Undang Nomor 31 Tahun 1999 sebagaimana telah diperbarui dalam Undang-Undang Nomor 20 Tahun 2001 tentang Pemberantasan Tindak Pidana Korupsi dan peraturan perundangan lainnya yang dijadikan sebagai upaya baik materiil maupun formiil penanggulangan tindak pidana korupsi (Fitriati, 2014). Salah satu faktor yang berpengaruh dalam lemahnya pemberantasan korupsi di Indonesia adalah pemberian sanksi yang tidak menimbulkan efek jera bagi koruptor. Masih banyak perangkat hukum yang lemah dan malah memberikan sebuah realitas yang ironi kepada masyarakat ketika koruptor malah diberikan sebuah previllage menjadikan sebuah cerminan yang nyata bahwa perangkat hukum tidak bermuara pada keadilan dan perlindungan masyarakat (Hartanti, 2009).

Eksistensi pidana mati di Indonesia juga telah disikapi oleh Mahkamah Konstitusi yang tetap mempertahankan bahwa sanksi pidana mati masih tetap menjadi salah satu sanksi pidana untuk kejahatan-kejahatan tertentu. Hal ini didasari dengan sanksi pidana mati tidak bertentangan hak hidup dalam Pasal 28A sampai 28 I UUD 1945 yang juga dibatasi oleh Pasal 28 J UUD 1945 yang diperkuat dengan International Covenant on Civil and Political Rights (ICCPR) dan Undang-Undang Nomor 39 Tahun 1999 tentang HAM yang ditafisrkan dengan menyatakan bahwa HAM harus digunakan untuk menghargai HAM orang lain untuk mencapai sebuah ketertiban umum dan keadilan sosial (Bonitua, Pujiyono, \& Purwoto, 2017). Sehingga penerapan sanksi pidana mati untuk koruptor masih dapat diberlakukan karena korupsi itu sendiri juga telah melanggar hak asasi orang lain.

Status keadaan Indonesia masih dalam keadaan darurat. Hal ini disampaikan oleh Presiden Republik Indonesia, Joko Widodo melalui Badan Nasional Penanggulangan Bencana (BNPB) menetapkan pandemi Covid-19 berstatus sebagai Bencana NonAlam yang dikategorikan sebagai bencana nasional dan itu masih berlaku sampai saat ini dengan dibuktikan dikeluarkannya Keputusan Presiden Nomor 12 Tahun 2020 tentang Penyebaran Corona Virus Disease 2019 (Covid-19) sebagai Bencana Nasional. Pandemi Covid-19 yang terjadi di Indonesia memberikan dampak yang luas bagi kehidupan masyarakat, Pemutusan Hubungan Kerja (PHK) naik signifikan, dirumahkan, mobilitas perusahaan terganggu karena pembatasan aktivitas, ranah UMKM jatuh bahkan tidak dapat beroperasi lagi, melihat dampak yang dirasakan seluruh masyarakat, wajar apabila masa pandemi Covid-19 ini dapat menjadi faktor pendorong bagi orang untuk melakukan kejahatan (Hidayat, 2020). 
Kasus yang menjerat Mentri Sosial, Jualiari Batubara dalam kasus suap Bantuan Sosial Kementerian Sosial RI menjadi bukti nyata program yang seharusnya memberikan stimulus bagi masyarakat untuk bertahan di masa pandemi ini, malah menjadi ladang korupsi pejabat tinggi terkait. Hal ini pula memberikan sebuah fakta bahwa pandemi Covid-19 dapat menjadi pendorong seseorang melakukan kajahatan. Jerat pidana yang dapat dikenakan kepada koruptor adalah pidana mati sebagaimana diatur dalam Pasal 2 Ayat (1) dan (2) UU Tipikor. Namun dalam praktiknya sampai saat ini penjatuhan pidana mati kepada koruptor belum pernah sama sekali dilakukan dalam sejarah penegakanhukum tindak pidana korupsi di Indonesia, Hal ini didasari oleh masih lemahnya substansi formulasi pidana mati dalam UU Tipikor yang hanya diatur dalam satu pasal yaitu Pasal 2 ayat (2), frasa keadaan tertentu yang masih menjadi multitafsir (Astuti, 2016).

Penjelasan Pasal 2 ayat (2) dari syarat hukuman mati dapat dijatuhkan kepada koruptor yang melakukan korupsi pada "keadaaan tertentu" dirumuskan sebagai berikut :

"Yang dimaksud dengan keadaan dengan 'keadaan tertentu' dalam ketentuan ini dimaksudkan sebagai pemberatan bagi pelaku tindak pidana korupsi apabila tindak pidana tersebut dilakukan pada waktu negara dalam keadaan bahaya sesuai dengan undang-undang yang berlaku, pada waktu terjadi bencana alam nasional, sebagai pengulangan tindak pidana korupsi, atau pada waktu negara dalam keadaan krisis ekonomi dan moneter"

Pandemi Covid-19 ditetapkan sebagai bencana non-alam yang bersifat bencana nasional. beberapa rangkaian peristiwa dan kebijakan (darurat kesehatan masyarakat dan darurat bencana non-alam) diatas kiranya dapat dijadikan sebagai dasar bahwa pada saat ini Indonesia sudah memasuki level Negara dalam keadaan bahaya sebagaimana diatur dalam Penjelasan Pasal 2 ayat (2) UU Tipikor tentang keadaan tertentu. Konsekuensi yuridis dari rangkaian peristiwa diatas adalah bahwa seseorang yang melakukan tindak korupsi sebagaimana memenuhi rumusan Pasal 2 UU Tipikor, maka penegak hukum dapat menuntut maupun menjatuhkan pidana mati terhadap terdakwa. Walaupun tindakan para koruptor dianggap sebagai suatu kesalahan yang harus dipertanggungjawabkan secara hukum, fakta tidak pernah dijatuhkannya eksekusi pidana mati menjadikan Indonesia sebagai komoditas baru bagi pelaku tindak pidana korupsi. Hingga saat ini hakim belum pernah menjatuhkan vonis pidana mati bagi pelanggar Pasal 2 UU Tipikor. Dengan demikian, sekarang merupakan saat yang tepat bagi para penegak hukum khususnya hakim dalam menerapkan pidana mati terhadap koruptor pada masa pandemi Covid-19 ini (Muqorobin \& Arief, 2020) 
UIRLawReview. 5(1): 49-58

\section{Kesimpulan}

atau penelitian mengenai kebijakan pidana mati bagi koruptor dan juga harus adanya sinkronisasi antara komponen hukum, komponen Aparat Penegak Hukum dan komponen kesadaran hukum dalam hal ini masyarakat. Kedua, Formulasi penjautuhan pidana mati terhadap koruptor pada masa pandemi Covid-19 dalam undang-undang perlu lebih dikaji mendalam terkait frasa 'keadaan tertentu', Namun terhadap fakta yang ada dan konsekuensi yuridis dari UU Tipikor, Hakim sebagai salah satu Aparat Penegak Hukum dapat melakukan sebuah penemuan hukum apabila masih terdapat keabstrakan dalam formulasi penjatuhan pidana mati dengan cara menggali, mengikuti dan memahami nilai-nilai hukum dan rasa keadilan yang hidup dalam masyarakat. 


\section{Daftar Pustaka}

Amirullah, A. (2013). Tindak Pidana Korupsi dan Sanksi Pidana Mati Perspektif Keadilan Hukum. Al-Daulah: Jurnal Hukum Dan Perundangan Islam, 3(2), 323-355. https://doi.org/10.15642/ad.2013.3.2.323-355

Anjari, W. (2020). Penerapan Pidana Mati Terhadap Terpidana Kasus Korupsi. MasalahMasalah Hukum, 49(4), 432-442. https://doi.org/10.14710/mmh.49.4.2020.432-442

Anshari, \& Fajrin, M. (2020). Urgensi Ancaman Hukuman Pidana Mati Pada Pelaku Tindak Pidana Korupsi (Analisis Yuridis Normatif Terhadap Kebijakan Hukum Pidana/Penal Policy Sanksi Pidana Mati di Indonesia). Res Judicata, 3(1), 26-50.

Arief, B. N. (2013). Kebijakan Reformulasi Ancaman Pidana Mati Tindak Pidana Korupsi Dalam Peraturan Perundang-Undangan. Masalah-Masalah Hukum. https://doi.org/10.14710/mmh.42.1.2013.23-33

Ariyanti, V. (2019). Kebijakan Penegakan Hukum Dalam Sistem Peradilan Pidana Indonesia. Jurnal Yuridis. https://doi.org/10.35586/jyur.v6i2.789

Astuti, P. B. W. P. E. S. (2016). Problem Yuridis Penerapan Sanksi Pidana Mati Terhadap Tindak Pidana Korupsi Menurut Undang-Undang Nomor 31 Tahun 1999 Jo UndangUndang Nomor 20 Tahun 2001. Diponegoro Law Journal, 5(4), 1-12.

Batubara, R. F. (2014). Kebijakan Formulasi Pidana Mati Terhadap Pelaku Tindak Pidana Korupsi Di Indonesia. LAW REFORM. https://doi.org/10.14710//r.v10i1.12458

Bonitua, Y. D., Pujiyono, \& Purwoto. (2017). Terhadap Penjatuhan Pidana Mati. Diponegoro Law Journal, 6(1), 1-18.

Detik News. (2020). Mensos Juliari Batubara Tersangka Suap Bansos, Ini Konstruksi Kasusnya. Retrieved December 9, 2020, from www.news.detik.com website: https://news.detik.com/berita/d-5283490/mensos-juliari-batubara-tersangka-suapbansos-ini-konstruksi-kasusnya/1

Fitriati. (2014). Analisis Perkembangan Sistem Peradilan Pidana Ditinjau dari Perspektif Pengadilan Tindak Pidana Korupsi. Jurnal Yustisia, 90(31), 73-82.

Hartanti, E. (2009). Tindak Pidana Korupsi (Kedua). Jakarta: Sinar Grafika.

Hidayat, R. (2020). Potret Penegakan Hukum Kala Pandemi Covid-19. Retrieved December 10, 2020, from www.hukumonline.com website: https://www.hukumonline.com/berita/baca//t5ec7411c5efdc/potret-penegakanhukum-kala-pandemi-covid-19

Iftitahsari. (2020). Hukuman Mati Dalam Pemberantasan Korupsi.

Institute For Criminal Justice Reform. (2020). Hentikan Narasi Populis Pidana Mati untuk Tindak Pidana Korupsi. Retrieved December 13, 2020, from https://icjr.or.id website: https://icjr.or.id/hentikan-narasi-populis-pidana-mati-untuk-tindak-pidana-korupsi/

Katimin, H. (2020). Kerugian Keuangan Negara atau Perekonomian Negara Dalam Menentukan Hukuman Mati Pada Tindak Pidana Korupsi. SASI, 26(1), 39. https://doi.org/10.47268/sasi.v26i1.210 
Manan, B. (2001). Perkembangan Pemikiran dan Pengaturan Hak Asasi Manusia di Indonesia. Jakarta: Yayasan Hak Asasi Manusia, Demokrasi dan Supremasi Hukum.

Marzuki, P. M. (2017). Penelitian Hukum (Revisi). Jakarta: PT Kharisma Putra Utama.

Muqorobin, M. K., \& Arief, B. N. (2020). Kebijakan Formulasi Pidana Mati dalam UndangUndang Pemberantasan Tindak Pidana Korupsi pada Masa Pandemi Corona Virus Disease 2019 (COVID-19) Berdasarkan Perspektif Pembaharuan Hukum Pidana. Jurnal Pembangunan Hukum Indonesia, 2(3), 387-398. https://doi.org/10.14710/jphi.v2i3.387-398

Surahmad. (2016). Kontroversi Kebijakan Hukuman Mati Bagi Koruptor Di Indonesia. Pusdiknas : Jurnal IImiah Kebijakan Nasional Dan Internasional, 2(3).

Toule, E. R. M. (2013). Eksistensi Ancaman Pidana Mati Dalam Undang-Undang Tindak Pidana. Jurnal Hukum Prioris, 3(3), 103-110.

Yanto, O. (2017). Penjatuhan Pidana Mati Pelaku Tindak Pidana Korupsi dalam Keadaan Tertentu. Jurnal Legislasi Indonesia, 14(1), 49-56. Retrieved from http://ejurnal.peraturan.go.id/index.php/jli/article/download/76/pdf 